\title{
ЗНАЧЕННЯ М-ХОЛІНОРЕЦЕПТОРІВ У ЗМІНАХ ОКСИДАТИВНИХ ПРОЦЕСІВ ПРИ РОЗВИТКУ АДРЕНАЛІНОВОГО УШКОДЖЕННЯ МІОКАРДА У ВИСОКО- ТА НИЗЬКОСТІЙКИХ ДО ГОСТРОЇ ГІПОКСИЧНОЇ ГІПОКСІЇ ЩУРІВ
}

Вступ. У зв'язку з розвитком гіпоксії, при більшості патологічних станів стає необхідним вивчення індивідуальної реактивності організму.

Мета дослідження - оцінити роль холінергічної регуляції про- й антиоксидантної системи в гомогенаті серця високо- та низькостійких до гіпоксії (ВГ, НГ) щурів-самців при адреналіновому ушкодженні міокарда (АУМ).

Методи дослідження. Досліди виконано на ВГ і НЕ безпородних щурах-самцях масою 180-220 г. Адреналінове ушкодження міокарда викликали адреналіном (1 мг/кг), дослідження проводили через 24 год після ін'єкції. Впливали на М-холінорецептори карбахоліном (0,4 мкг/кح) і атропіну сульфратом (1 мг/кح). У серці визначали концентрацію дієнових кон'югатів (ДК), ТБК-активних продуктів (ТБК-ап), активність супероксиддисмутази (СОД), вміст вітаміну Е (віт. Е).

Результати й обговорення. У контрольній групі (К) активність СОД, вміст віт. Е були вищими у НГ тварин. При АУМ відзначали зростання концентрації ДК у ВГ щурів, вмісту ТБК-ап - у ВГ і НГ, активності СОД - у ВГ. Різниці між ВГ і НГ тваринами не спостерігали. Після введення карбахоліну, порівняно з К, збільшилися концентрація ТБК-ап, активність СОД, вміст віт. Е. При АУМ на фроні використання карбахоліну вміст ТБК-ап у ВГ щурів був меншим, ніж після введення карбахоліну, не відрізнявся від такого в К, а у НГ тварин - залишався вищим, ніж у К. Активність СОД, вміст віт. Е у ВГ і НГ щурів перевищували значення К та АУМ, а у ВГ тварин - також показники після введення карбахоліну. Різниці між ВГ і НГ щурами не було. Після введення атропіну, порівняно з К, у ВГ тварин зріс вміст віт. E, у НГ-ТБК-ап і віт. E. При АУМ на фроні використання атропіну збільшилася концентрація ДК у ВГ і НГ щурів, ТБК-ап - у НГ. У ВГ тварин вміст ТБК-ап був на рівні $К$.

Висновки. Розвиток адреналінового ушкодження міокарда залежить від резистентності до гіпоксії та холінергічної регуляції організму. Стимуляція М-холінорецепторів сприяє активації антиоксидантної системи, обмежує розвиток оксидантного стресу, а їх блокада спричинює реалізацію оксидантних механізмів у НГ щурів, збільшує різницю в перебізі АУМ між ВГ і НГ тваринами.

КЛЮЧОВІ СЛОВА: гіпоксія; резистентність; пероксидне окиснення ліпідів; антиоксидантна система; серце; адреналін; атропін; карбахолін.

ВСТУП. У патології серцево-судинної системи провідне місце займає проблема некротичних ушкоджень міокарда, які викликає розвиток гіпоксії в ньому. Одними з причин такого стану можуть бути надмірний вплив стресу, виділення катехоламінів. Гіпоксія супроводжує практично всі патологічні процеси. При ній у клітинах фрормується каскад реакцій [1, 2]: зменшення напруження оксигену в крові й тканинах $\rightarrow$ зниження АТФ $\rightarrow$ накопичення іонів кальцію $\rightarrow$ підвищення активності фросорорилаз $\rightarrow$ електрична дестабілізація мембран $\rightarrow$ збільшення проникності мембран для іонів $\rightarrow$ роз'єднання процесів окис(с) О. В. Денефіль, Т. Я. Ярошенко, 2020. нення і фросфрорилювання $\rightarrow$ загибель клітин на фоні зростання енергодефіциту. При гіпоксії, впливі катехоламінів в організмі збільшується швидкість вільнорадикальних реакцій, яка залежить від рівня метаболізму, організації системи антиоксидантного захисту, зокрема антирадикальних фрерментів (глутатіонпероксидаза, супероксиддисмутаза (СОД), каталаза) та природних антиоксидантів (токоферол, аскорбінова кислота), які сповільнюють окисні процеси [2-4].

Виникнення, перебіг і наслідки захворювання значно залежать від реактивності організму [5], а в популяціях існують особи з різною резистентністю до стресів, холоду, крововтрат, гіпоксії [6]. 
Мета дослідження - оцінити роль холінергічної регуляції про- й антиоксидантної системи в гомогенаті серця високо- та низькостійких до гіпоксії (ВГ, НГ) щурів-самців при адреналіновому ушкодженні міокарда (АУМ).

МЕТОДИ ДОСЛІДЖЕННЯ. ДосЛіди виконано на ВГ і НЕ безпородних щурах-самцях масою 180-220 г. Тварин поділили на 3 серії: 1-ша дослід; 2-га-карбахолін; 3-тя-атропін. У кожній серії було по 2 групи - контрольна (К), адреналінове ушкодження міокарда.

Групи тварин утримували на стандартному харчовому раціоні віварію протягом усього періоду та з вільним доступом до води для пиття. Для моделювання АУМ щурам внутрішньом'язово вводили $1 \%$ розчин адреналіну гідрохлориду з розрахунку 1 мг/кг маси. Дослідження проводили через 24 год після ін'єкції. Для оцінки ролі автономної нервової системи виконували стимуляцію М-холінорецепторів карбахоліном (з розрахунку 0,4 мкг/кг за 5 хв до введення адреналіну внутрішньочеревно) та їх блокаду $0,1 \%$ розчином атропіну сульфату (з розрахунку 1 мг/кг за 25 хв до ін'єкції адреналіну внутрішньом'язово). Усім тваринам проводили гістологічне дослідження серця на рівні обох шлуночків, під час якого було підтверджено виникнення некрозів у мікропрепаратах, зафрарбованих за Гейденгайном.

Усі досліди виконували в першій половині дня в спеціально відведеному приміщенні при температурі $18-22{ }^{\circ} \mathrm{C}$, відносній вологості 40 60 \% і освітленості 250 лк. Експерименти проведено з дотриманням норм Європейської конвенції про захист хребетних тварин, що використовуються для дослідних та інших наукових цілей (Страсбург, 18.03.1986р.), ухвали Першого на- ціонального конгресу з біоетики (Київ, 2001) і наказу МОЗ України від 23.09.2009 р. № 690.

Евтаназію щурів проводили шляхом тотального кровопускання із серця після попереднього використання тіопентал-натрієвого наркозу (60 мг $\cdot \mathrm{K}^{-1}$ маси тіла тварини внутрішньочеревно). Застосовуючи загальноприйняті методики, в гомогенаті серця визначали стан пероксидного окиснення ліпідів (ПОЛ) за вмістом дієнових кон'югатів (ДК), ТБК-активних продуктів (ТБК-ап) та антиоксидантної системи (АОC), зокрема активність супероксиддисмутази, вміст вітаміну E (віт. Е) [7-9].

Статистичну обробку цифррових даних виконано за допомогою програмного забезпечення Excel ("Microsoft", CШA) i STATISTICA 6.0 ("Statsoft", США). Достовірність різниці значень між незалежними кількісними величинами визначали при нормальному розподілі за критерієм Стьюдента, в інших випадках - за допомогою непараметричних методів. Зміни вважали достовірними при $\mathrm{p} \leq 0,05$. Відмінності між величинами вважали достовірними за вірогідності альтернативної гіпотези не менше ніж 0,95 [10].

РЕЗУЛЬТАТИ Й ОБГОВОРЕННЯ. У 1-Й ДОслідній серії тварин протягом перших 15 хв від початку експерименту відмічено смертність щурів: серед ВГ вона становила $(11,9 \pm 5,0) \%$, серед НГ - $(29,0 \pm 5,8) \%(p<0,05)$.

У контрольних ВГ і НГ тварин серії "Дослід" вміст продуктів ПОЛ не відрізнявся, але активність СОД і вміст віт. Е були значно вищими у НГ щурів (табл. 1). Через 24 год АУМ концентрація ДК достовірно збільшилась тільки у ВГ тварин (на 10,45 \%), а вміст ТБК-ап достовірно зріс як у ВГ (на 50,99 \%), так і у НГ щурів (на 64,44 \%). Активність СОД у ВГ тварин підвищилась на

Таблиця 1 - Зміни вмісту продуктів пероксидного окиснення ліпідів та антиоксидантів у гомогенаті серця щурів при адреналіновому ушкодженні міокарда (M士m)

\begin{tabular}{|c|c|c|c|c|}
\hline \multirow{4}{*}{ Показник } & \multicolumn{4}{|c|}{ Група } \\
\hline & \multicolumn{2}{|c|}{$\mathrm{K}$} & \multicolumn{2}{|c|}{ AYM } \\
\hline & $\mathrm{B} \Gamma(\mathrm{n}=6)$ & $\mathrm{H} \Gamma(n=6)$ & $\mathrm{B} \Gamma(\mathrm{n}=11)$ & $\mathrm{H \Gamma}(\mathrm{n}=10)$ \\
\hline & 1 & 2 & 3 & 4 \\
\hline ДК, мКМоль/Кг & $134,20 \pm 2,10$ & $\begin{array}{c}137,10 \pm 3,20 \\
p_{1-2}>0,05\end{array}$ & $\begin{array}{c}148,30 \pm 3,20 \\
p_{1-3}<0,01\end{array}$ & $\begin{array}{c}141,40 \pm 2,10 \\
p_{2-4}>0,05 \\
p_{3-4}>0,05\end{array}$ \\
\hline ТБК-ап, мкмоль/кг & $15,10 \pm 0,90$ & $\begin{array}{c}13,50 \pm 0,70 \\
p_{1-2}>0,05\end{array}$ & $\begin{array}{c}22,80 \pm 1,10 \\
p_{1-3}<0,001\end{array}$ & $\begin{array}{c}22,20 \pm 0,60 \\
p_{2-4}<0,001 \\
p_{3-4}>0,05\end{array}$ \\
\hline $\begin{array}{l}\text { СОД, ×103, } \\
\text { од. акт./год×кг }\end{array}$ & $10,58 \pm 0,20$ & $\begin{array}{c}11,17 \pm 0,17 \\
p_{1-2}>0,05\end{array}$ & $\begin{array}{c}12,41 \pm 0,47 \\
p_{1-3}<0,02\end{array}$ & $\begin{array}{c}11,55 \pm 0,51 \\
p_{2-4}>0,05 \\
p_{3-4}>0,05\end{array}$ \\
\hline Віт. Е, кмоль/кг & $77,66 \pm 0,32$ & $\begin{array}{c}79,21 \pm 0,19 \\
\mathrm{p}_{1-2}>0,05\end{array}$ & $\begin{array}{c}78,47 \pm 1,52 \\
p_{1-3}>0,05\end{array}$ & $\begin{array}{c}78,01 \pm 0,83 \\
\mathrm{p}_{2-4}>0,05 \\
\mathrm{p}_{3-4}>0,05\end{array}$ \\
\hline
\end{tabular}


17,30 \%. Достовірної різниці між показниками ВГ і НГ щурів у цій серії не спостерігали. Активація процесів ПОЛ при АУМ у ВГ тварин супроводжувалася зростанням активності СОД, а у НГ щурів такого ефректу не відмічали. Очевидно, більша вихідна потужність АOC забезпечує постійне знешкодження вільних радикалів, а при підвищенні вимог до організму антиоксидантів недостатньо.

При АУМ на фроні введення карбахоліну смертності серед ВГ тварин не було, а серед НГ щурів вона становила $(13,6 \pm 5,2) \%$, час загибелі тварин - від 25 хв до 10 год.

Після введення карбахоліну, порівняно $3 \mathrm{~K}$, зросли концентрація ТБК-ап (у ВГ щурів - на $68,21 \%$, у НГ - на 59,26 \%), активність СОД (у ВГ тварин - на 10,26\%, у НГ - на 14,54 \%) і вміст віт. Е (у ВГ щурів - на 5,48 \%, у НГ - на 3,08 \%) (табл. 2). Через 24 год АУМ, викликаного на фроні використання карбахоліну, концентрація ДК достовірно не змінилася ні у ВГ, ні у НГ тварин. Вміст ТБК-ап у ВГ щурів був меншим порівняно 3 результатами після введення карбахоліну i достовірно не відрізнявся від контрольних цифрр, а у НГ тварин показники залишалися більшими від інтактного контролю. Активність СОД, вміст віт. Е і у ВГ, і у НГ щурів перевищували значення К та АУМ дослідної групи, а у ВГ тварин - також показники після введення карбахоліну. Достовірної різниці між показниками ВГ і НГ щурів у цій групі не відмічено.
Активацію процесів ПОЛ при АУМ спостерігали тільки у НГ тварин, хоча вона і супроводжувалася збільшенням показників АОС. У ВГ щурів відзначали зменшення вмісту продуктів ПОЛ на фоні збільшення значень АОС. Очевидно, переважання холінергічних впливів спричинює активацію AOC, що забезпечує знешкодження вільних радикалів у ВГ тварин. Щоправда, такої активації недостатньо для НГ щурів, що може вказувати на уроджену недостатність парасимпатичних впливів, які, як відомо, мають киснезберігальний есрект і запобігають розвитку гіпоксії.

При АУМ на фоні введення атропіну смертність серед ВГ тварин становила $(8,7 \pm 4,1) \%$, а серед $\mathrm{H} \Gamma-(32,7 \pm 5,3) \%$.

Після введення атропіну, порівняно з К, у ВГ щурів показники, що характеризують ПОЛ, не змінилися, але на 3,89 \% збільшився вміст віт. Е. У НГ тварин збільшився вміст ТБК-ап (на 117,78 \%) і віт. E (на 3,22 \%) (табл. 3). Можна думати, що блокада М-холінорецепторів провокує розвиток оксидантного стресу, а холінергічні впливи сприяють його обмеженню. Очевидно, сильні холінергічні впливи у ВГ щурів меншою мірою блокуються атропіном, ніж слабкі у НГ тварин. Такий ефект може бути пов'язаний з більшою чутливістю М-холінорецепторів при зниженій їх кількості.

Через 24 год АУМ, змодельованого на фоні введення атропіну, відмічено зростання концентрації ДК у ВГ і НГ тварин, вмісту ТБК-ап - у

Таблиця 2 - Зміни вмісту продуктів пероксидного окиснення ліпідів та антиоксидантів у гомогенаті серця щурів при адреналіновому ушкодженні міокарда на фоні введення карбахоліну (M士m)

\begin{tabular}{|c|c|c|c|c|}
\hline \multirow{4}{*}{ Показник } & \multicolumn{4}{|c|}{ Група } \\
\hline & \multicolumn{2}{|c|}{ карбахолін } & \multicolumn{2}{|c|}{ карбахолін+АУМ } \\
\hline & $\mathrm{B} \Gamma(\mathrm{n}=12)$ & $\mathrm{H} \Gamma(\mathrm{n}=6)$ & $\mathrm{B} \Gamma(\mathrm{n}=6)$ & $H \Gamma(n=6)$ \\
\hline & 5 & 6 & 7 & 8 \\
\hline ДК, мкмоль/кг & $\begin{array}{c}140,70 \pm 2,60 \\
p_{1-5}>0,05\end{array}$ & $\begin{array}{c}141,80 \pm 2,90 \\
p_{2-6}>0,05 \\
p_{5-6}>0,05\end{array}$ & $\begin{array}{c}140,40 \pm 7,30 \\
\mathrm{p}_{1-7}>0,05 \\
\mathrm{p}_{3-7}>0,05 \\
\mathrm{p}_{5-7}>0,05\end{array}$ & $\begin{array}{c}143,60 \pm 2,40 \\
\mathrm{p}_{2-8}>0,05 \\
\mathrm{p}_{4-8}>0,05 \\
\mathrm{p}_{6-8}>0,05 \\
\mathrm{p}_{7-8}>0,05\end{array}$ \\
\hline ТБК-ап, мкмоль/кг & $\begin{array}{c}25,40 \pm 0,90 \\
p_{1-5}<0,05\end{array}$ & $\begin{array}{c}21,50 \pm 1,20 \\
\mathrm{p}_{2-6}<0,05 \\
\mathrm{p}_{5-6}<0,05\end{array}$ & $\begin{array}{c}19,40 \pm 1,90 \\
\mathrm{p}_{1-7}>0,05 \\
\mathrm{p}_{3-7}>0,05 \\
\mathrm{p}_{5-7}<0,05\end{array}$ & $\begin{array}{c}22,30 \pm 1,20 \\
\mathrm{p}_{2-8}<0,05 \\
\mathrm{p}_{4-8}>0,05 \\
\mathrm{p}_{6-8}>0,05 \\
\mathrm{p}_{7-8}>0,05\end{array}$ \\
\hline $\begin{array}{l}\text { СОД, ×103, } \\
\text { од. акт./годхкг }\end{array}$ & $\begin{array}{c}11,79 \pm 0,46 \\
p_{1-5}<0,05\end{array}$ & $\begin{array}{c}13,07 \pm 0,45 \\
p_{2-6}<0,01 \\
p_{5-6}>0,05\end{array}$ & $\begin{array}{c}14,14 \pm 0,21 \\
\mathrm{p}_{1-7}<0,001 \\
\mathrm{p}_{3-7}<0,01 \\
\mathrm{p}_{5-7}<0,002\end{array}$ & $\begin{array}{c}14,00 \pm 0,29 \\
\mathrm{p}_{2-8}<0,001 \\
\mathrm{p}_{4-8}<0,001 \\
\mathrm{p}_{6-8}>0,05 \\
\mathrm{p}_{7-8}>0,05\end{array}$ \\
\hline ВІт. Е, кмоль/кг & $\begin{array}{c}81,92 \pm 0,35 \\
p_{1-5}<0,001\end{array}$ & $\begin{array}{c}81,65 \pm 0,65 \\
p_{2-6}<0,01 \\
p_{5-6}>0,05\end{array}$ & $\begin{array}{c}83,97 \pm 0,27 \\
p_{1-7}<0,001 \\
p_{3-7}<0,01 \\
p_{5-7}<0,002\end{array}$ & $\begin{array}{c}83,11 \pm 0,23 \\
\mathrm{p}_{2-8}<0,001 \\
\mathrm{p}_{4-8}<0,001 \\
\mathrm{p}_{6-8}>0,05 \\
\mathrm{p}_{7-8}>0,05\end{array}$ \\
\hline
\end{tabular}


Таблиця 3 - Зміни вмісту продуктів пероксидного окиснення ліпідів та антиоксидантів у гомогенаті серця щурів при адреналіновому ушкодженні міокарда на фоні введення атропіну (M士m)

\begin{tabular}{|c|c|c|c|c|}
\hline \multirow{4}{*}{ Показник } & \multicolumn{4}{|c|}{ Група } \\
\hline & \multicolumn{2}{|c|}{ атропін } & \multicolumn{2}{|c|}{ атропін+АУМ } \\
\hline & $B \Gamma(n=12)$ & НГ $(n=6)$ & ВГ $(n=6)$ & НГ $(n=6)$ \\
\hline & 9 & 10 & 11 & 12 \\
\hline ДК, мКМоль/Кг & $\begin{array}{c}135,10 \pm 2,20 \\
p_{1-9}>0,05\end{array}$ & $\begin{array}{c}134,30 \pm 2,50 \\
p_{2-10}>0,05 \\
p_{9-10}>0,05\end{array}$ & $\begin{array}{c}146,40 \pm 2,30 \\
p_{1-11}<0,002 \\
p_{3-11}>0,05 \\
p_{9-11}<0,05\end{array}$ & $\begin{array}{c}157,90 \pm 4,30 \\
\mathrm{p}_{2-12}<0,001 \\
\mathrm{p}_{4-12}<0,002 \\
\mathrm{p}_{10-12}<0,01 \\
\mathrm{p}_{11-12}<0,05\end{array}$ \\
\hline ТБК-ап, мкмоль/кг & $\begin{array}{c}14,50 \pm 0,60 \\
p_{1-9}>0,05\end{array}$ & $\begin{array}{l}29,40 \pm 1,70 \\
p_{2-10}<0,001 \\
p_{9-10}<0,001\end{array}$ & $\begin{array}{c}17,10 \pm 0,90 \\
\mathrm{p}_{1-11}>0,05 \\
\mathrm{p}_{3-11}<0,002 \\
\mathrm{p}_{9-11}<0,05\end{array}$ & $\begin{array}{l}36,50 \pm 3,20 \\
p_{2-12}<0,001 \\
p_{4-12}<0,001 \\
p_{10-12}>0,05 \\
p_{11-12}<0,001\end{array}$ \\
\hline $\begin{array}{l}\text { СОД, ×103, } \\
\text { од. акт./год ×кг }\end{array}$ & $\begin{array}{c}10,92 \pm 0,24 \\
p_{1-9}>0,05\end{array}$ & $\begin{array}{c}11,58 \pm 0,15 \\
p_{2-10}>0,05 \\
p_{9-10}<0,05\end{array}$ & $\begin{array}{c}9,70 \pm 0,20 \\
\mathrm{p}_{1-11}<0,001 \\
\mathrm{p}_{3-11}<0,001 \\
\mathrm{p}_{9-11}<0,01\end{array}$ & $\begin{array}{c}12,00 \pm 0,56 \\
\mathrm{p}_{2-12}>0,05 \\
\mathrm{p}_{4-12}>0,05 \\
\mathrm{p}_{10-12}>0,05 \\
\mathrm{p}_{11-12}<0,002\end{array}$ \\
\hline Віт. Е, кмоль/кг & $\begin{array}{c}80,68 \pm 0,65 \\
p_{1-9}<0,002\end{array}$ & $\begin{array}{c}81,76 \pm 0,35 \\
p_{2-10}<0,001 \\
p_{9-10}>0,05\end{array}$ & $\begin{array}{c}80,21 \pm 0,53 \\
p_{1-11}<0,01 \\
p_{3-11}>0,05 \\
p_{9-11}>0,05\end{array}$ & $\begin{array}{l}78,02 \pm 1,13 \\
p_{2-12}>0,05 \\
p_{4-12}>0,05 \\
p_{10-12}<0,05 \\
p_{11-12}>0,05\end{array}$ \\
\hline
\end{tabular}

НГ щурів. Причому в НГ тварин значення були вищими порівняно з ВГ щурами та більшими порівняно із серією "Дослід". У ВГ тварин значення ДК були такими ж, як у серії “Дослід”, а ТБК-ап - достовірно меншими, і вони не перевищували результатів інтактного контролю. У ВГ щурів відзначено зниження активності СОД, що, очевидно, можна пояснити витратами її на знешкодження супероксид-аніон-радикала, але збільшувався вміст віт. Е. У НГ тварин показники АОС не змінювались. Імовірно, у ВГ щурів атропін має модулюючий вплив на процеси ПОЛ, діючи на центральні холінорецептори, тоді як у НГ тварин він спричинює ушкоджувальний ефрект, активуючи ПОЛ, і діє на перисреричні рецептори, що потребує подальшого дослідження.

ВИСНОВКИ. Розвиток адреналінового ушкодження міокарда залежить від резистентності до гіпоксії та холінергічної регуляції організму. Стимуляція М-холінорецепторів сприяє активації антиоксидантної системи, обмежує розвиток оксидантного стресу в усіх тварин, а їх блокада спричинює реалізацію оксидантних механізмів у низькостійких до гіпоксії щурів, збільшує різницю в перебізі адреналінового ушкодження між високо- і низькостійкими до гіпоксії тваринами.

\section{СПИСОК ЛІТЕРАТУРИ}

1. Corcoran A. Hypoxia-inducible factor signaling mechanisms in the central nervous system / A. Corcoran, J. J. O'Connor // Acta Physiol. (Oxf). - 2013. - 208, No. 4. - P. 298-310.

2. Механизмы фрормирования острой экзогенной гипоксии и возможности ее фармакологической коррекции антигипоксантами / Д. В. Сосин, О. Е. Шалаева, А. В. Евсеев, П. Д. Шабанов // Обзоры по клинич. фрармакологии и лекарственной терапии. -2015. -13, № 1. - C. 1-24.

3. Antioxidant and cytoprotective responses to redox stress / J. Mathers, J. A. Fraser, M. McMahon [et al.] // Biochem. Soc. Symp. - 2004. - No. 71. - P. 157-176.
4. Colombo M. L. An update on vitamin E, tocopherol and tocotrienol - perspectives / M. L. Colombo // Molecules. - 2010. - 15, No. 4. - P. 2103-2113.

5. A possible role for systemic hypoxia in the reactive component of pulmonary hypertension in heart failure / B. J. Taylor, C. R. Mojica, T. P. Olson [et al.] // Journal of Cardiac Failure. - 2013. - 19, Issue 1. P. 50-59.

6. Устойчивость к гипоксии у людей пожилого возраста с гипертонической болезнью: влияние Кардиоаргинина / О. В. Коркушко, Е. Д. Осьмак, Д. Д. Осьмак, Г. В. Дужак // Кровообіг та гемостаз. - 2015. № 1-2. - С. 31-37. 
7. Хышиктуев Б. С. Методы определения продуктов перекисного окисления липидов в конденсате выдыхаемого воздуха и их клиническое значение / Б. С. Хышиктуев, Н. А. Хышиктуева, В. Н. Иванов // Клинич. лаб. диагностика. - 1996. - № 3. - С. 13-15.

8. Чевари С. Роль супероксиддисмутазы в окислительных процессах клетки и метод определения ее в биологических материалах / С. Чевари, И. Чаба Й. Секей // Лаб. дело. - 1985. - № 11. - С. 678-681.
9. Чернулкенс Р. Ч. Одновременное фрлюорометрическое определение концентрации витаминов А и Е в сыворотке крови / Р. Ч. Чернулкенс, Л. С. Грибаускас // Лаб. дело. - 1984. - № 6. - С. 362-365.

10. Лапач С. Н. Статистические методы в медико-биологических исследованиях с использованием Excel / С. Н. Лапач, А. В. Чубенко, П. Н. Бабич - К. : Морион, 2000. - 320 с.

\section{REFERENCES}

1. Corcoran, A. \& O'Connor, J.J. (2013). Hypoxiainducible factor signaling mechanisms in the central nervous system. Acta Physiol. (Oxf.), 208 (4), 298-310.

2. Sosin, D.V., Shalaeva, O.E., Evseev, A.V., \& Shabanov, P.D. (2015). Mekhanismy formirovaniya ostroy ekzogennoy gipoksii i vosmozhnosti ego farmakologicheskoy korrektsii antihipoksantami [Mechanisms of the formation of acute exogenous hypoxia and the possibility of its pharmacological correction with antihypoxants]. Obzory po klinicheskoj pharmakologii i lekarstvennoy terapii - Reviews on Clinical Pharmacology and Drug Therapy, 13 (1), 1-24 [in Russian].

3. Mathers, J., Fraser, J.A., McMahon, M., Saunders, R.D., Hayes, J.D. \& McLellan, L.I. (2004). Antioxidant and cytoprotective responses to redox stress. Biochem. Soc. Symp., 71, 157-176.

4. Colombo, M.L. (2010). An update on vitamin E, tocopherol and tocotrienol - perspectives. Molecules, 15(4), 2103-2113.

5. Taylor, B.J., Mojica, C.R., Olson, T.P., Woods, P.R., Frantz, R.P. \& Johnson, B.D, (2013). A possible role for systemic hypoxia in the reactive component of pulmonary hypertension in heart failure. Journal of Cardiac Failure, 19 (1), 50-59.

6. Korkushko, O.V., Osmak, E.D., Ocmak, D.D., \& Duzhak, G.V. (2015). Ustoychivost k gipoksii u lyudey pozhilogo vozrzsta s gipertonicheskoy boleznyu: vliyanie Cardioarginina [Resistance to hypoxia in elderly people with essential hypertension: the effect of Cardioarginin]. Krovoobih i hemostas - Blood Circulation and Hemostasis, 1-2, 31-37 [in Russian].

7. Khyshiktyev, B.S., Khyshiktyeva, N.A. \& Ivanov, V.N. (1996). Metody opredeleniya produktov perekisnogo okisleniya lipidov $v$ kondensate vydykhaemogo vozdukha i ikh klinicheskoe znachenie [Methods for determination of lipid peroxidation products in exhaled air condensate and their clinical significance]. Klinicheskaya laboratornaya diagnostica - Clinical Laboratory Diagnostic, 3, 13-15 [in Russian].

8. Chevari, S., Chaba, I. \& Sekei, I. (1985). Rol superoksiddismutazy $v$ okislitelnykh protsessakh kletki i metod opredeleniya ego $v$ biologicheskikh materialakh [The role of superoxide dismutase in the oxidative processes of the cell and the method for its determination in biological materials]. Laboratornoye delo - Laboratoty Work, 11, 678-681 [in Russian].

9. Chernulkens, R.Ch., \& Gribauskas, L.S. (1984). Odnovremennoe fluometricheskoe opredelenie kontsentratsii vitaminov A i E v syvorotki krovi [Simultaneous fluorometric determination of the concentration of vitamins $A$ and $E$ in blood serum]. Laboratornoye delo - Laboratoty Work, 6, 362-365 [in Russian].

10. Lapach, S.N., Chubenko, A.V. \& Babich, P.N. (2000). Statisticheskie metody $v$ mediko-biologicheskikh issledovaniyahh s ispolzovaniem Excel [Statistical methods in biomedical research using Excel]. Kyiv: Morion [in Russian].

О. В. Денефиль, Т. Я. Ярошенко

ТЕРНОПОЛЬСКИЙ НАЦИОНАЛЬНЫЙ МЕДИЦИНСКИЙ УНИВЕРСИТЕТ ИМЕНИ И. Я. ГОРБАЧЕВСКОГО МОЗ УКРАИНЫ

\section{ЗНАЧЕНИЕ М-ХОЛИНОРЕЦЕПТОРОВ В ИЗМЕНЕНИЯХ ОКСИДАТИВНЫХ ПРОЦЕССОВ ПРИ РАЗВИТИИ АДРЕНАЛИНОВОГО ПОВРЕЖДЕНИЯ МИОКАРДА У ВЫСОКО- И НИЗКОУСТОЙЧИВЫХ К ОСТРОЙ ГИПОКСИЧЕСКОЙ ГИПОКСИИ КРЫС}

\section{Резюме}

Вступление. В связи с развитием гипоксии, при большинстве патологических состояний становится необходимым изучение индивидуальной реактивности организма.

Цель исследования - оценить роль холинергической регуляции про- и антиоксидантной системы в гомогенате сердца высоко- и низкоустойчивых к гипоксии (ВГ, НГ) крыс-самцов при адреналиновом повреждении миокарда (АПМ).

Методы исследования. Опыты выполнены на ВГ и НГ беспородных крысах-самцах массой 180-220 ح. Адреналиновое повреждение миокарда вызывали адреналином (1 мг/к2), исследования проводили через 
24 ч после инъекции. Влияли на М-холинорецепторы карбахолином (0,4 мкг/к2) и атропина сульфратом (1 мг/кг). В сердце определяли концентрацию диеновых конъюгатов (ДК), ТБК-активных продуктов (ТБК-ап), активность супероксиддисмутазы (СОД), содержание витамина Е (вит. Е).

Результаты и обсуждение. В контрольной группе (К) активность СОД, содержание вит. Е были выше в НГ животных. При АПМ отмечали возрастание концентрации ДК у ВГ крыс, содержания ТБК-ап у ВГ и НГ, активности СОД - у ВГ. Разницы между ВГ и НГ животными не наблюдали. После введения карбахолина, по сравнению с К, увеличились концентрация ТБК-ап, активность СОД, содержание вит. E. При АПМ на фроне использования карбахолина содержание ТБК-ап у ВГ крыс было меньше, чем после введения карбахолина, не отличалось от такого в К, а у НГ животных - оставалось выше, чем в К. Активность СОД, содержание вит. Е у ВГ и НГ крыс превышали значения К и АМП, а у ВГ животных - также показатели после введения карбахолина. Разницы между ВГ и НГ крысами не было. После введения атропина, по сравнению с К, у ВГ животных возросло содержание вит. Е, у НГ - ТБК-ап и вит. Е. При АПМ на фоне использования атропина увеличилась концентрация ДК у ВГ и НГ крыс, ТБК-ап -у НГ. УВГживотных содержание ТБК-ап было на уровне $K$.

Выводы. Развитие адреналинового повреждения миокарда зависит от резистентности к гипоксии и холинергической регуляции организма. Стимуляция М-холинорецепторов способствует активации антиоксидантной системы, ограничивает развитие оксидантного стресса, а их блокада вызывает реализацию оксидантных механизмов у НГ крыс, увеличивает разницу в течении АПМ между ВГ и НГ животными.

КЛЮЧЕВЫЕ СЛОВА: гипоксия; резистентность; перекисное окисление липидов; антиоксидантная система; сердце; адреналин; атропин; карбахолин.

O. V. Denefil, T. Ya. Yaroshenko

I. HORBACHEVSKY TERNOPIL NATIONAL MEDICAL UNIVERSITY

\section{SIGNIFICANCE OF M-CHOLINORECEPTORS IN CHANGES OF OXIDATIVE PROCESSES IN THE DEVELOPMENT OF ADRENALINE MYOCARDIAL DAMAGE IN HIGH- AND LOW-RESISTANT TO HYPOXIC HYPOXIA RATS}

\section{Summary}

Introduction. It becomes necessary to study the individual reactivity of the body due to the development of hypoxia in most pathological conditions.

The aim of the study - to evaluate the role of cholinergic regulation of the pro- and antioxidant system in the heart homogenate of high- and low-resistance to hypoxia (HR, LR) male rats in adrenaline myocardial damage (AMD).

Research Methods. The experiments were performed on HR and LR male rats weighing 180-220 grams. AMD was induced with adrenaline $(1 \mathrm{mg} / \mathrm{kg})$, and experiments were performed 24 hours after injection. The effect on $\mathrm{M}$-cholinoreceptors was carried out with carbacholine $(0.4 \mu \mathrm{g} / \mathrm{kg})$ and atropine sulfate $(1 \mathrm{mg} / \mathrm{kg})$. Diene conjugates (DC), TBA-active products (TBA-ap), superoxide dismutase activity (SOD), and vitamin E content (vit E) were determined in the heart.

Results and Discussion. In control (C) SOD, vit. E were higher in LR. At AMD DC in HR, TBA-ap in HR and $L R, S O D$ - in HR increased. There was no difference between HR and LR. After injection of carbacholin, compared with $C$, increased TBA-ap, SOD, vit. E. When AMD on the background of carbacholin, TBA-ap in HR were smaller than after carbacholin, did not differ from $C$, and in $L R$ remained higher $C$. SOD, vit. $E$ in $H R$ and $L R$ exceeded the values of $C$ and $A M D$, and in HR also carbacholin. There was no difference between HR and LR. After injection of atropine, compared with $C$, in HR increased vit. E, in LR - TBA-ap and vit. E. At AMD and atropine, were increased $D C$ in HR and LR, TBA-ap in LR, more in LR. In HR TBA-ap were at the level of $C$.

Conclusions. The development of adrenaline damage to the heart depends on resistance to hypoxia and cholinergic regulation of the body. Stimulation of $\mathrm{M}$-cholinoreceptors promotes the activation of the antioxidant system, limits the development of oxidative stress, and their blockade causes the implementation of oxidative mechanisms in LR rats, increases the difference in the course of AMD between HR and LR animals.

KEY WORDS: hypoxia; resistance; lipid peroxidation; antioxidant system; heart; adrenaline; atropine; carbacholin.

Отримано 05.11.20

Адреса для листування: О. В. Денефріль, Тернопільський національний медичний університет імені І. Я. Горбачевського МОз України, майдан Волі, 1, Тернопіль, 46001, Україна, e-mail: denefil@tdmu.edu.ua. 